\title{
A Review and Interspecific Comparison of Nocturnal and Cathemeral Strepsirhine Primate Olfactory Behavioural Ecology
}

\author{
Ian C. Colquhoun \\ Department of Anthropology and The Centre for Environment and Sustainability, The University of Western Ontario, London, ON, \\ Canada N6A 5C2 \\ Correspondence should be addressed to Ian C. Colquhoun, colquhou@uwo.ca
}

Received 13 November 2010; Revised 2 February 2011; Accepted 17 March 2011

Academic Editor: Lesley Rogers

Copyright (๑) 2011 Ian C. Colquhoun. This is an open access article distributed under the Creative Commons Attribution License, which permits unrestricted use, distribution, and reproduction in any medium, provided the original work is properly cited.

This paper provides a comparative review of the known patterns of olfactory behavioural ecology among the nocturnal strepsirhine primates and the cathemeral lemurid genus Eulemur. Endemic to Madagascar, all Eulemur species exhibit both diurnality and nocturnality (i.e., cathemerality), and are gregarious, making them an interesting group of taxa to compare with the nocturnal strepsirhines. This paper represents the first comparative review of patterns of olfactory communication among the nocturnal strepsirhines and the cathemeral Eulemur species. Inductive assessment of these comparative data indicates that olfactory communication serves multiple functions in both groups, including individual recognition, sex recognition, indication of social dominance, and coordination of mating behaviour. However, the urine-washing behaviour characteristic of many nocturnal strepsirhines has no clear homologue among Eulemur species (although the latter may use urine droplets in scent marking). Despite sparse and scattered comparative data, it appears that Eulemur species exhibit different olfactory communication patterns that are associated with differing social organizations in this genus.

\section{Introduction}

In their 2004 paper reviewing comparative data on latrine behaviour among lemur species, Irwin and coauthors [1] contended that, " ... the use of chemical signals in primate communication is well documented." On this point, they cited two fundamental sources: first, Alain Schilling's 1979 review paper, "Olfactory Communication in Prosimians" [2], and second, Gisela Epple's 1986 review of primate olfactory behaviour, "Communication by Chemical Signals" [3].

There are two important things to note concerning this pair of key publications on primate olfactory behaviour. The first is that, although it has been 32 and 25 years, respectively, since these works were published, both continue to be required reading in the field of primate olfactory communication. The second is that both these publications predate the 1987 definition of primate species with both diurnal and nocturnal activity patterns as being "cathemeral," or active "through the day" (i.e., through the 24-hour daily cycle) [4]. This definition ushered in the extensive attention the lemuriform primate genus Eulemur has received concerning this distinctive activity pattern, (e.g., [5-7], and references therein).

Genus Eulemur and all the other lemuriform primates native to Madagascar, together with the lorisiform primates of Africa and Asia, represent a major adaptive radiation within the Order Primates - the Suborder Strepsirhini. These primates retain the ancestral mammalian characteristic of the rhinarium (or "wet nose"). Strepsirhine primates include all the lemur species of Madagascar and the Comoro Islands, the lorises of south and southeastern Asia, and the pottos and galagos (or, bushbabies) of sub-Saharan Africa. In the closing section section of his 1979 paper, Schilling [2] remarked on the apparent distinction between the predominantly deferred olfactory signals of nocturnal strepsirhines and the combined direct olfactory and visual signalling of diurnal strepsirhines, stating, "It would be interesting to study this aspect of olfactory communication in species that are intermediate between the two types (emphasis added), that is, which are greagrious to the extent that they live in family groups, and which are more or less nocturnal, like Hapalemur griseus, 
Avahi laniger, and Lemur mongoz." Thus, the present paper represents the first comparative review of olfactory communication exhibited by nocturnal strepsirhine primates and the cathemeral Eulemur species. The major aim of this paper is to provide an initial assessment of the types and contexts of olfactory communication of the nocturnal strepsirhines relative to those of the cathemeral genus Eulemur (as well as the cathemeral lemurid species Hapalemur griseus).

\section{Strepsirhine Olfactory Biology in Comparative Perspective}

Before comparing patterns of olfactory communication amongst nocturnal and cathemeral strepsirhine primates, it is useful to first consider strepsirhine olfactory biology in broader primate and mammalian comparative contexts. Relative to many other mammalian orders (e.g., rodents, artiodactyls, perissodactyls, carnivores), primates have historically been regarded as microsmatic [8-10]. But the olfactory systems of strepsirhine and haplorhine primates also exhibit considerable differences in the relative proportions and complexities of their anatomical structures [10-19]. Early work in this area produced the proposal that those primate species possessing functional vomeronasal organs (VNOs) might be regarded as relatively macrosmatic while those primate species without functional VNOs could be considered microsmatic, (e.g., [8]). Further, these comparative anatomical data have also been interpreted as indicating, in general, relatively sensitive olfaction among strepsirhines, tarsiers, and platyrrhines, and less keen olfactory abilities among catarrhine primates (i.e., Old World cercopithecoid monkeys and hominoids); these latter taxa are considered more visually adapted, exhibiting specializations such as trichromatic vision $[8-12,14,19-26]$. More recently, however, this interpretation and classification schema has been discarded due to mounting evidence that there is not a direct correspondence between the presence or relative sizes of olfactory structures and olfactory function, (e.g., $[10,19,27$, 28]).

In terms of comparative anatomy, the extant strepsirhine primates (together with the extinct adapoid primates of the Eocene epoch) are considered to have retained the primitive eutherian mammal "nasal ground plan" [10]. All strepsirhine primates possess the rhinarium, the naked, moist tissue surrounding the nostrils, which is also found in many other mammalian taxa but has been lost in all haplorhine primates (i.e., New World monkeys, Old World monkeys, and hominoids $[10,29])$. The available comparative anatomical data for members of the Order Primates indicate that both the VNO and the entire vomeronasal complex (VNC) are most fully developed in strepsirhines $[13,14,30]$, and likely play critical roles in discrimination among chemical classes of odourants [19] and in pheromonal communication [20]. The available anatomical data on species in the haplorhine infraorders Tarsiiformes (tarsiers) and Platyrrhini (New World, or platyrrhine, monkeys) indicate that these taxa also possess VNCs that are "structurally comparable" [30] to those found in strepsirhines $[10,14,17,18,30]$; however, the functional role of the VNC has not been fully examined across these former taxa $[21,30]$.

The accessory olfactory bulb (AOB) of the accessory olfactory system (AOS) is described as large to very large relative to body size in those strepsirhine species that have been examined [15]. There is considerable variation in $\mathrm{AOB}$ size relative to body size in those strepsirhine and platyrrhine species for which there are data [15]. The AOB is described as relatively well developed in platyrrhine species, but the available comparative data also indicate that AOBs in New World monkeys are generally reduced in absolute size compared to those of strepsirhine species [15]. In those Old World monkey species (Cercopithecoidea) studied thus far, the AOS is absent in adults $[10,21,30]$. In the ape species (Hominoidea) that have been studied, including humans, the $\mathrm{AOB}$ is absent in adults $[10,15]$. If the VNO is present in hominoid species (again, including humans), it appears vestigial in structure and is thought to likely be nonfunctional $[10,13-16,19,20,22-24,30]$. Among the strepsirhines studied to date, nocturnal strepsirhines are reported to both have larger AOBs [15], and larger olfactory bulbs (OBs) [10] than diurnal strepsirhines. Barton and colleagues [12] reported that among nocturnal strepsirhines, there is a positive correlation between the proportion of fruit in the overall diet and the relative size of the $\mathrm{OB}$, (see also [25]). Haplorhine primates, by contrast, have relatively small OBs in comparison to most other mammals $[19,26]$.

There have been several reports noting that olfaction in primates is relatively under-studied and remains poorly understood (e.g., $[10,20,21,26])$. Recently, the view has also been expressed that interpreting primate olfactory reception and processing as being functionally divided between the main olfactory system (MOS) and the AOS is too simplistic $[8,10,19,20,27,28]$. Specifically, the complexity of primate olfaction is not reflected in a functional interpretation that sees the MOS primarily detecting airborne volatile odours from a variety of stimuli in the environment, such as food or predators $[19,27]$, and the AOS being primarily sensitive to heavy, nonvolatile, fluid-borne chemical stimuli, such as urine and scent-marks, as well as pheromones, that communicate sociosexual information $[10,19,27]$. Rather, the emerging view is that there must be a degree of overlap, or integration, in the functioning of the MOS and AOS $[8,10,19,20,27,28]$.

This more nuanced interpretation of primate olfaction has been pushed ahead by innovative studies that have made novel applications of research techniques. For example, advances in genomic analyses have made possible the comparison of olfactory receptor (OR) gene families coding for olfactory receptor proteins (ORPs) in different primate species and other mammals, (e.g., $[9,11,18,19$, $23,24,28])$. Advances have also been realized in several recent studies of primate olfaction through the use of gas chromatography-mass spectrometry (GC-MS) to identify both the volatile components of the glandular secretions used in scent marking, (e.g., [31-34]), and the chemical composition of urine [35].

Notably, genetic studies have provided new insights into primate olfactory function. Although testing across the 
Order Primates has not been exhaustive to this point, the V1R and V2R olfactory receptor (OR) gene families and the TRP2 gene (which is crucial for pheromone signal transduction in the VNO) have been examined across several primate genera. These preliminary assessments of the genetics of olfaction have shown that catarrhine primates, with their trichromatic vision, exhibit a significantly higher proportion of nonfunctional OR pseudogenes than do either platyrrhine monkeys or strepsirhines $[9,11,18,19,23,24]$. An exception to this taxonomic pattern is the platyrrhine genus Alouatta, the howler monkeys, which have evolved trichromatic vision via convergent evolution and exhibit a level of OR pseudogenization similar to that among catarrhine taxa [11]. Yet, this does not mean that cercopithecoids and hominoids (or Alouatta, for that matter) do not use, or respond to, olfactory communication $[19,29,36]$. Despite lacking the AOS as adults, some cercopithecoid monkeys do exhibit scentmarking behaviour (e.g., [37, 38]). Although scent-marking behaviour has not been recorded among hominoid taxa $[10,39,40]$, available comparative data show that specialized cutaneous scent glands, such as the axillary apocrine glands, are known in all hominoid genera $[10,39,40]$; this provides a likely channel for interindividual olfactory communication and individual recognition in hominoids, including humans [27, 39-42]. Similarly, recent GC-MS analyses of the volatile components in mandrill (Mandrillus sphinx) scent marks indicated that, despite the mandrill apparently lacking a functional AOS, individual odour profiles convey information about the signaller, including age, sex, dominance rank of adult males, and perhaps identity of the signaller [43]. Additionally, odour similarity between signaller and receiver is related to major histocompatibility (MHC) concordance, and represents a potential mechanism for mate selection by females in favour of MHC-diverse males [44]. These new insights into olfactory communication in a catarrhine primate seem to provide an example of the suggestion that, even without functional AOSs or VNOs, catarrhines can still detect and respond to sociosexual odour cues and pheromonal stimuli through ORPs that are expressed in the main olfactory epithelium [10, 19, 20, 22, 27, 28].

So, while we have an emerging picture of humans and other catarrhine primates being capable of responding to an array of odour cues, including chemosensory responses to volatile components of some odours [10, 19, 20, 27, $28,43,44]$, the available comparative data on strepsirhine primates (where we find species that exhibit retention of the rhinarium, well-developed AOSs, relatively large AOBs, functional VNOs, intact OR gene families coding for functional ORPs, plus functional integration of the AOSs and the MOSs), indicate that strepsirhine primate taxa experience considerable complexity in their olfactory communication $[10,19,20,28,35]$. The important role of scent marking and olfactory communication in strepsirhine behavioural ecology, particularly in regard to reproductive behaviour, has been recognized for decades, (e.g., [45]). Yet, despite this, and despite important comparative works like those by Schilling [2] and Epple [3], it is surprising how little-studied strepsirhine olfactory communication remains and how little we know with certainty about strepsirhine olfactory behavioural ecology. This relates to the general point raised repeatedly in the literature that research into primate olfaction lags far behind that on primate visual and vocal systems, for example, [10, 20, 21, 26]. For example, the comments of Rowell [46] over 30 years ago remain surprisingly current: "Prosimians are smelly animals... olfactory communication occurs both at a distance and in body contact, but monitoring the "conversation" presents difficulties for our olfactorily unsophisticated species and proceeds slowly." Over the last decade, for every peerreviewed paper dealing with primate olfaction, 115 dealing with primate vision have been published (e.g., see the PrimateLit database: http://primatelit.library.wisc.edu; see also [26]). From this, we can appreciate why Heymann [26] concluded that, "Thus, it is appropriate to consider olfaction as a sense that is still neglected in the study of nonhuman primates."

All this is by way of pointing out that the present, and any other, comparative review of olfactory behavioural ecology across strepsirhine primate species must rely on a body of information that is fragmentary and scattered. Thus, this review must be regarded as entirely preliminary. Recent taxonomies recognize at least 26 lorisiform strepsirhine species (i.e., the lorises, pottos, and galagos, or bushbabies; see [47]) while the number of recognized lemuriform strepsirhine species endemic to Madagascar approaches 100 and is still climbing [48-50]. For most of these lorisiform and lemuriform taxa, however, there is no information available on the behavioural ecology of their olfactory communication.

\section{Nocturnal and Cathemeral Strepsirhines: Comparative Data}

In order to review the literature relating to strepsirhine primate olfactory behavioural ecology as completely as possible, and given the scant literature that deals explicitly with primate olfaction (see above), it was also necessary to consult reports, on strepsirhine primate species, that have dealt primarily with other topics (such as social organization, social behaviour, ranging ecology, etc.), and glean whatever material could be found concerning olfactory communication. This entailed having to pull information from a sentence here or an anecdote there, in a literature that is very scattered (relevant material was found in publications that focused on primatology, anthropology, behaviour, chemical ecology, mammalogy, and zoology). This simply underscores the fact that the behavioural ecology of strepsirhine primate olfaction and olfactory behaviour remains both a poorly researched and poorly understood dimension of the overall behavioural ecology of these taxa. It also points to this area being an extremely fertile and promising area for future research on the behavioural ecology of strepsirhine primates (moreover, the same applies to the study of primate olfactory behavioural ecology in general, as several recent publications reflect, e.g., [20, 26-28, 42, 43, 51]). 


\subsection{Nocturnal Lemuriforms}

3.1.1. Genus Microcebus: The Mouse Lemurs. Microcebus murinus, the gray mouse lemur, is the lemuriform species for which the accessory olfactory system (AOS), including the vomeronasal organ, has most fully been investigated [52]. In M. murinus, male-male, male-female, and female-female socio-sexual interactions are mediated and coordinated by urinary chemosensory cues [53-55]. Studies of M. murinus in captivity have shown that male urinary marking behaviour decreases with age $[56,57]$. The suite of scent-marking behaviours known for the gray mouse lemur includes punctuated urine marking (sometimes with "perineal wiping"), head rubbing and muzzle or lip wiping, branch chewing with salivary deposition, and, especially, "urine washing" (where individuals purposefully urinate on their hands and feet), which accounts for over $80 \%$ of all scent-marking behaviours performed [2, 3, 58-61]. In a recent field study of the golden brown mouse lemur ( $M$. ravelobensis), Braune and colleagues [62] recognized two forms of scent marking: urine washing, and mouth wiping (sometimes with face and/or head rubbing).

3.1.2. Genus Mirza: The "Giant" Mouse Lemurs. Olfactory communication among Mirza during reproductive behaviour includes nasonasal, nasobody and nasogenital contact [63]. Both punctuated urine marking and urine trail marking occur, and experimental work indicates males can discriminate among the urine marks of conspecifics $[3,58]$. Both males and females anogenital scent mark, and, like Microcebus, Mirza also engages in salivary marking [59]. Notably, Mirza would also appear to exhibit flehmen (see photo Figure 8 in [59]—the caption reads, "The typical posture for smelling a mark of a conspecific; note the open mouth, and retracted tongue," emphasis added; cf. [64]).

3.1.3. Genus Cheirogaleus: The Dwarf Lemurs. Data on olfactory communication are available for the greater dwarf lemur (Cheirogaleus major) and the fat-tailed dwarf lemur ( $C$. medius). Both species exhibit punctuated urine marking and urine trail marking, as well as anogenital scent marking $[2,58]$, but the dwarf lemurs are notable for their specialized fecal marking of branches $[2,65]$, which Irwin and colleagues [1] identify as arboreal latrine behaviour. Dwarf lemur fecal marking may be related to territorial advertisement.

3.1.4. Genus Phaner: The fork-Marked Lemurs. Phaner stands out amongst the nocturnal lemuriforms because of the apparent absence of any form of urine marking in this genus $[2,66]$. Males may rarely scent mark branches with their throat gland [67]; more often, males use their throat gland to scent mark females during allogrooming bouts [66].

3.1.5. Genus Lepilemur: The Sportive Lemurs. Like most other nocturnal strepsirhines studied to date, sportive lemurs exhibit urine marking $[2,3,58]$. Only males are reported to anogenital scent mark [1-3]. Although Lepilemur species are totally arboreal, patterns of defecation produce terrestrial latrines that seem to be linked to resource defence $[1-3,68]$.

3.1.6. Genus Daubentonia: The Aye-Aye. Both sexes exhibit anogenital scent marking [2,69], and female anogenital scent marking increases during estrus [70]. Aye-ayes also engage in urine trail marking $[2,71,72]$.

3.1.7. Genus Avahi: The Woolly Lemurs. The woolly lemurs are not at all well-studied; there is a dearth of research on their behavioural ecology. I could not find any published information on the olfactory behavioural ecology of Avahi.

3.2. The Lorisiformes. All taxa that have been studied in this nocturnal primate infraorder (that is, the lorises, pottos, and galagos, or bushbabies) scent mark extensively with urine [58], and urine marking is much more frequent than glandular scent marking. Together with the lorisine genus Loris, all galagine primates studied to date (except the galago genus Euoticus) exhibit both urine washing and punctuated urine marking (or "rhythmic micturition") [7376]. Urine washing can occur in a variety of contexts, including mobbing behaviour, moving into an unfamiliar area, during agonistic and aggressive encounters, and, in social interactions, especially when a female is in estrus [7678]. Greater galagos (Otolemur crassicaudatus) have been shown experimentally to differentiate scent marks by sex and by individual [78, 79]. Allen's galago (Sciurocheirus alleni) shows high frequencies of urine marking in territorial boundary zones [80]. Scent marking seems also to function as a stress-reducing mechanism in the small-eared bushbaby (Otolemur garnettii) [81]. Urine washing in Loris, the slender loris, has been reported to often occur in the context of consuming noxious insect prey, both before catching the prey and after consuming the prey; urine washing would also occur if a loris was stung by an insect [82]. Loris females have also been observed to urine wash before they groom their infants-this has been proposed to possibly have an antipredator function when females "park" their infants while they forage (i.e., the possible anti-predator function of a female urine washing and then grooming her infant could be either that it provides an olfactory screen or barrier against potential predators, or that it acts as a form of predator mimicry while the infant is "parked") [82].

All lorisine primates studied thus far exhibit urine trail marking in addition to punctuated urine marking [2, 58, $76,83]$. In Loris, inter-sexual social interactions often see males either sniffing the muzzle or anogenital region of females $[82,84]$. During allogrooming bouts, Loris males and females will lick and rub a specialized brachial gland on their own face and body and on the body of the grooming partner [82]. Perodicticus, the potto, exhibits "genital scratch grooming" during which grooming partners of both sexes scent mark each other-this behaviour is not linked to reproduction [85]. In Perodicticus, urine marking may accompany allogrooming [86]. During allogrooming, pottos also mark each other with saliva and genital secretions [87]. Arctocebus, 
TABLE 1: Comparative interspecific profiles of scent marking behaviours among nocturnal strepsirhine genera (i.e., lemuriforms, galagines, and lorisines) and the cathemeral lemurid genera Eulemur and Hapalemur, as derived from the published literature on these taxa [1-3, 52112]. Scent-marking behaviours: 1, urine washing; 2, punctuated urine marking; 3, urine-trail marking; 4, muzzle wipe/branch chewing (saliva deposition); 5, flehmen; 6, fecal marking; 7, latrine behaviour; 8, anogenital scent marking; 9, head marking (males).

\begin{tabular}{|c|c|c|c|c|c|c|c|c|c|}
\hline \multirow[b]{2}{*}{ Strepsirhine taxon (refs) } & \multicolumn{9}{|c|}{ Scent-marking behaviours } \\
\hline & 1 & 2 & 3 & 4 & 5 & 6 & 7 & 8 & 9 \\
\hline \multicolumn{10}{|l|}{ Nocturnal lemuriforms } \\
\hline Microcebus $[2,3,52-62]]$ & + & + & - & + & $?$ & - & - & - & + \\
\hline Mirza $[3,58,59,63,64]$ & - & + & + & + & + & - & - & $\begin{array}{c}+ \\
\text { (Both } \\
\text { sexes) }\end{array}$ & $?$ \\
\hline Cheirogaleus $[1,2,58,65]$ & - & + & + & $?$ & $?$ & + & - & + & $?$ \\
\hline Phaner $[2,6,66,67]$ & - & $?$ & $?$ & $?$ & $?$ & - & - & $-(?)$ & $\begin{array}{c}+ \\
\text { (Male throat } \\
\text { gland) }\end{array}$ \\
\hline Lepilemur $[1-3,58,68]$ & - & + & - & $?$ & $?$ & - & + & $\begin{array}{c}+ \\
\text { (Males) }\end{array}$ & $?$ \\
\hline $\begin{array}{l}\text { Daubentonia } \\
{[2,68,69,71,72]}\end{array}$ & - & $?$ & + & $?$ & $?$ & - & - & + & - \\
\hline Avahi (no refs.) & $-(?)$ & $?$ & $?$ & $?$ & $?$ & $-(?)$ & $-(?)$ & $+(?)$ & $?$ \\
\hline \multicolumn{10}{|l|}{ Galagines $[58,73-83]$} \\
\hline Galagoides & + & + & - & $?$ & $?$ & - & - & $?$ & $?$ \\
\hline Galago & + & + & - & $?$ & $?$ & - & - & $?$ & $?$ \\
\hline Euoticus & - & - & - & $?$ & $?$ & - & - & $?$ & $?$ \\
\hline Sciurocheirus & + & + & - & $?$ & $?$ & - & - & $?$ & $?$ \\
\hline Otolemur & + & + & - & $?$ & $?$ & - & - & + & $?$ \\
\hline \multicolumn{10}{|l|}{$\begin{array}{l}\text { Lorisines } \\
{[2,58,76,82,84-89]}\end{array}$} \\
\hline Loris & + & + & + & $?$ & + & - & - & $+^{*}$ & - \\
\hline Nycticebus & - & + & + & $?$ & $?$ & - & - & $?$ & - \\
\hline Perodicticus & - & + & + & $?$ & + & - & - & $+^{*}$ & - \\
\hline Arctocebus & - & + & + & $?$ & $?$ & - & - & $\begin{array}{c}+^{*} \\
+^{*}= \\
\text { "passing } \\
\text { over" }\end{array}$ & - \\
\hline \multicolumn{10}{|l|}{$\begin{array}{l}\text { Cathemeral lemuriforms } \\
{[1-3,90-113]}\end{array}$} \\
\hline Eulemur & - & + & - & + & + & - & - & + & + \\
\hline Hapalemur & - & + & - & + & $?$ & - & + & + & - \\
\hline
\end{tabular}

the golden potto, exhibits distinctive "passing over" scentmarking behaviour, where the male straddles the female and scent-marks her dorsum [85]. "Passing over" has also been observed in Loris and Perodicticus [82]. Flehmen behaviour has recently been described in these two genera [82]; in Loris, it followed the licking of a urine mark while in Perodicticus it followed a male sniffing a substrate in a female's home range [82]. Nycticebus, the slow loris, apparently possesses a "fear scent" (an "Angstgeruch"), and this has also been suggested for Perodicticus and Arctocebus (especially in the context of mother-infant alarm communication [86]); similarly, Loris has been suggested to have an anti-predator "alarm pheromone" [82]. Male pygmy slow lorises (N. pygmaeus) countermark, with urine, on both male and female urine marks. Males countermark the urine marks of other males with significant amounts of urine. In this species, estrus females appear to prefer countermarking males [88], and males whose scent-mark odours are already familiar to them [89].

3.3. The Cathemeral Lemurids. Comparative data on the olfactory communication of cathemeral lemurids, a good deal of it from field research reported since 1990, reveals both broad similarities with nocturnal strepsirhines (see Table 1; $[1-3,52-113])$, as well as interesting, and unforeseen, distinctions among the cathemeral lemurids themselves (see Table 2; [1-3, 90-113]). In addition to anogenital scentmarking, most cathemeral lemurid species also make use 
TABle 2: Comparative interspecific profiles of scent marking behaviours among lemurid species of the genera Eulemur and Hapalemur, as derived from the published literature on these taxa [1-3, 90-113]. The patterns seen in the two pair-bonded Eulemur species, E. mongoz and E. rubriventer, are very similar to each other, and contrast in significant ways to the patterns exhibited amongst the Eulemur taxa that occur in multimale, multifemale social groups (i.e., the E. fulvus group of taxa, E. macaco, and E. coronatus).

\begin{tabular}{|c|c|c|c|c|c|c|}
\hline $\begin{array}{l}\text { Scent-marking } \\
\text { behaviours }\end{array}$ & E. fulvus group & E. macaco & E. coronatus & E. mongoz & E. rubriventer & Hapalemur \\
\hline $\begin{array}{l}\text { Anogenital scent-mark } \\
\text { surfaces }\end{array}$ & + & + & + & + & + & + \\
\hline Urine mark & + & + & + & + & $?$ & + \\
\hline $\begin{array}{l}\text { Bite mark (saliva } \\
\text { deposition) males }\end{array}$ & + & + & + & Cheek rubbing & $\begin{array}{l}\text { Teeth grinding } \\
\text { during } \\
\text { inter-group } \\
\text { encounters }\end{array}$ & + \\
\hline Anogenital mark & & & & $\mathrm{M} \rightarrow \mathrm{F}$ & $\mathrm{M} \rightarrow \mathrm{F}$ & \\
\hline Conspecifics & $\mathrm{M} \rightarrow \mathrm{F}$ & $\mathrm{M} \rightarrow \mathrm{F}$ & $\mathrm{M} \rightarrow \mathrm{F}$ & $\mathrm{F} \rightarrow \mathrm{M}$ & $\mathrm{F} \rightarrow \mathrm{M}$ & $\mathrm{M} \rightarrow \mathrm{F}$ \\
\hline HeadMarking (males) & + & + & + & + & + & - \\
\hline $\begin{array}{l}\text { Hand/palmarmarking } \\
\text { (males) }\end{array}$ & + & + & + & + & + & $\begin{array}{l}\text { Antebrachial } \\
\text { gland marking }\end{array}$ \\
\hline Anogenital sniff $(\mathrm{M} \rightarrow \mathrm{F})$ & + & + & + & + & + & + \\
\hline Self-marking & $\begin{array}{l}\text { Observed in } \\
\text { captivity }\end{array}$ & $\begin{array}{l}\text { Observed in } \\
\text { captivity }\end{array}$ & - & - & - & $\begin{array}{l}\text { M marks tail with } \\
\text { antebrachial } \\
\text { glands to "stink } \\
\text { fight" other Ms }\end{array}$ \\
\hline $\begin{array}{l}\text { Marking during } \\
\text { inter-group encounters }\end{array}$ & $\begin{array}{l}\text { Variable.Vocal \& } \\
\text { visual displays; } \\
\text { some marking }\end{array}$ & $\begin{array}{l}\text { Vocal and visual } \\
\text { displays }\end{array}$ & $\begin{array}{l}\text { Vocal \& visual } \\
\text { displays }\end{array}$ & + & $\begin{array}{c}+ \\
\text { (Incl. F } \\
\text { overmarking of } \\
\text { M anogen marks) }\end{array}$ & $\begin{array}{c}+ \\
\text { (Both substrate } \\
\text { and self-marking) }\end{array}$ \\
\hline Flehmen & $?$ & $\begin{array}{c}+ \\
\text { (pers. obs.) }\end{array}$ & $?$ & $?$ & $?$ & $?$ \\
\hline Latrine behaviour & - & - & - & - & - & + \\
\hline
\end{tabular}

of punctuated urine marking (deposited concurrently with the anogenital scent mark — cf. [35], where lemurids, including several Eulemur taxa, are characterized as "nonurine marking" species). I could not find any report, however, of punctuated urine marking in Eulemur rubriventer, the red-bellied lemur (also, Tecot, personal communication). Urine washing has never been reported in any cathemeral strepsirhine. Head marking by males occurs across the entire genus Eulemur.

Notably, the mongoose lemur (E. mongoz) and the redbellied lemur (E. rubriventer), which are both pair-bonded and territorial species, share similar patterns of olfactory communication [90-94]. These two Eulemur species contrast in their patterns of scent-marking behaviour vis-à-vis their congeners that exhibit multi-male, multi-female social organization: the crowned lemur (E. coronatus) $[95,96]$, the black lemurs (E. macaco and E. flavifrons) [97-101], and the brown lemur taxa (E. fulvus, E. rufus, E. sanfordi, E. albifrons, E. rufifrons, E. collaris, and E. cinereiceps) [102109]. I could not find any report of male "bite marking" (a behaviour in which a male chews a branch and deposits a salivary mark) in either mongoose or red-bellied lemurs. Although male bite marking has not been reported in these two species, male mongoose lemurs have been observed to cheek rub branches [91]; whether or not saliva is deposited in this process is unclear. In both of these pair-bonded Eulemur species, anogenital scent marking of conspecifics of the opposite sex is performed by both sexes, rather than only males anogenitally scent marking females (a pattern seen in the multi-male, multi-female group-living Eulemur species). Scent marking also figures prominently during intergroup encounters with conspecific groups in both E. mongoz and $E$. rubriventer, including females overmarking male anogenital marks in E. rubriventer [93, 94]. These differential patterns of scent-marking behaviour were only uncovered as emergent patterns because of this comparative review of olfactory communication in the genus Eulemur and other strepsirhine primates.

In contrast to mongoose and red-bellied lemurs (i.e., the two Eulemur species that exhibit pair bonding), there is a tendency among the crowned, black, and brown lemurs (i.e., the Eulemur taxa that exhibit multi-male, multi-female social groups), to engage in vigorous visual and vocal intergroup displays rather than intergroup displays involving concerted scent marking. In captivity, however, adjacently housed groups of brown lemurs have been observed to exhibit scent marking in addition to the aforementioned visual and vocal inter-group displays. Self-marking has been reported in captive brown lemurs (E. fulvus) [2], and the gray gentle lemur Hapalemur griseus [113]. Male Hapalemur griseus rub 
their antebrachial glands on their tail in advance of facing off against other males in tail-waving "stink fights"; these are similar in nature to the "stink fight" displays of male ring-tailed lemurs (Lemur catta) [44]. I have observed a captive male black lemur (E. macaco) self-mark by repeatedly making palmar markings over his tail. Flehmen behaviour has been reported in the diurnal L. catta ([64]; personal observation). I have also observed a wild male black lemur (E. macaco) exhibit flehmen during the breeding seasononce when he exhibited the characteristic facial grimace associated with flehmen after actively sniffing the air, and a second time after the same male sniffed a tree branch while in proximity to a juvenile male from another social group [100]. The latrine behaviour reported in Hapalemur [1] is unique among the cathemeral lemurids.

\section{Conclusions}

In broad terms, cathemeral lemurids exhibit many forms of olfactory communication that are the same as, or similar to, those seen in nocturnal strepsirhine species, including punctuated urine marking, anogenital scent marking of conspecifics, male overmarking of female scent marks, and, in the two pair-bonded Eulemur species, scent marking in territorial boundary zones. Within these broadly similar patterns of olfactory communication across strepsirhine primate species, there are notable distinctions in olfactory communication within the cathemeral genus Eulemur. One pattern is exhibited by the two pair-bonding and territorial Eulemur species (i.e., E. mongoz and E. rubriventer); a second pattern is seen in the Eulemur taxa that occur in larger multi-male, multi-female social groups. Although it should have been within the power of socioecological theory to generate predictions regarding differences in the olfactory behavioural ecology of Eulemur species with differing forms of social organization, it is also notable that such differences were uncovered by an intensive inductive review process. Indeed, although many gaps persist in our knowledge of the strepsirhine primates, further inductive collation of both published quantitative data on, and descriptive observations of, these species could well uncover other previously unrecognized emergent patterns in their behavioural ecology.

While key insights on strepsirhine behavioural ecology have come from increased field research on these taxa over the last 20 years, it is telling that much fundamental information on strepsirhine olfactory communication still derives from research conducted in the 1970s and early 1980s. This highlights the extent to which our understanding of the olfactory behavioural ecology of Eulemur species in particular, and strepsirhine primates more generally, is still only in a preliminary state. Future fieldwork should strive to record as much contextual data as possible regarding where and when various forms of olfactory communication are used (for example, what forms of olfactory communication may be exclusive to breeding behaviour? Are there types of olfactory communication that may occur primarily during inter-group encounters in zones of home range overlap or at territorial boundaries?). Additional insights on similarities and differences among strepsirhine primate species in their chemosensory biology and olfactory communication can be expected from future studies that link odour, genetics, behaviour, and ecology $[20,26,35,50,114]$.

\section{Acknowledgments}

A brief version of this paper was presented in the Symposium on "Olfactory Communication in Nocturnal and Cathemeral Primates" held during the XXII Congress of the International Primatological Society in Edinburgh, Scotland, August 38, 2008. The author thanks to Dr. Sharon Gursky for the invitation to participate in that symposium and for encouragement in the first place to undertake this comparative look at the behavioural ecology of olfactory communication in nocturnal and cathemeral strepsirhines. Comments provided by two anonymous reviewers and Dr. Lesley Rogers, editor of the paper, were most useful and helped to improve earlier drafts of the paper. The paper was also improved by detailed comments that were kindly provided by Dr. Susan Muir. Heartfelt thanks must go to Caleigh Farrell, the author's student research assistant, for the untold hours and boundless energy she devoted to helping him track down the relevant sources in a very scattered literature. This paper is dedicated to the late Dr. Shelley Saunders.

\section{References}

[1] M. T. Irwin, K. E. Samonds, J. L. Raharison, and P. C. Wright, "Lemur latrines: observations of latrine behavior in wild primates and possible ecological significance," Journal of Mammalogy, vol. 85, no. 3, supplement, pp. 420-427, 2004.

[2] A. Schilling, "Olfactory communication in prosimians," in The Study of Prosimian Behavior, G. A. Doyle and R. D. Martin, Eds., pp. 461-542, Academic Press, New York, NY, USA, 1979.

[3] G. Epple, "Communication by chemical signals," in Comparative Primate Biology, Volume 2A: Behavior, Conservation and Ecology, G. Mitchell and J. Erwin, Eds., pp. 531-580, Alan R. Liss, New York, NY, USA, 1986.

[4] I. Tattersall, "Cathemeral activity in primates: a definition," Folia Primatologica, vol. 49, pp. 200-202, 1987.

[5] D. J. Curtis and M. A. Rasmussen, "Cathemerality in Lemurs," Evolutionary Anthropology, vol. 11, no. 1, supplement, pp. 83-86, 2002.

[6] I. Tattersall, "The concept of cathemerality: history and definition," Folia Primatologica, vol. 77, no. 1-2, pp. 7-14, 2006.

[7] G. Donati and S. M. Borgognini-Tarli, "From darkness to daylight: cathemeral activity in primates," Journal of Anthropological Sciences, vol. 84, no. 1, pp. 7-32, 2006.

[8] T. D. Smith and K. P. Bhatnagar, "Microsmatic primates: reconsidering how and when size matters," Anatomical Record. Part B, vol. 279, no. 1, pp. 24-31, 2004.

[9] J. Zhang and D. M. Webb, "Evolutionary deterioration of the vomeronasal pheromone transduction pathway in catarrhine primates," Proceedings of the National Academy of Sciences of the United States of America, vol. 100, no. 14, pp. 8337-8341, 2003. 
[10] T. D. Smith, J. B. Rossie, and K. P. Bhatnagar, "Evolution of the nose and nasal skeleton in primates," Evolutionary Anthropology, vol. 16, no. 4, pp. 132-146, 2007.

[11] Y. Gilad, V. Wiebe, M. Przeworski, D. Lancet, and S. Pääbo, "Loss of olfactory receptor genes coincides with the acquisition of full trichromatic vision in primates," PLoS Biology, vol. 2, no. 1, pp. 0120-0125, 2004.

[12] R. A. Barton, A. Purvis, and P. H. Harvey, "Evolutionary radiation of visual and olfactory brain system in primates, bats and insectivores," Philosophical Transactions of the Royal Society B, vol. 348, no. 1326, pp. 381-392, 1995.

[13] K. B. Døving and D. Trotier, "Structure and function of the vomeronasal organ," Journal of Experimental Biology, vol. 201, no. 21, pp. 2913-2925, 1998.

[14] K. P. Bhatnagar and E. Meisami, "Vomeronasal organ in bats and primates: extremes of structural variability and its phylogenetic implications," Microscopy Research and Technique, vol. 43, no. 6, pp. 465-475, 1998.

[15] E. Meisami and K. P. Bhatnagar, "Structure and diversity in mammalian accessory olfactory bulb," Microscopy Research and Technique, vol. 43, no. 6, pp. 476-499, 1998.

[16] E. B. Keverne, “The vomeronasal organ,” Science, vol. 286, no. 5440, pp. 716-720, 1999.

[17] S. Takami, "Recent progress in the neurobiology of the vomeronasal organ," Microscopy Research and Technique, vol. 58, no. 3, pp. 228-250, 2002.

[18] W. E. Grus, P. Shi, Y. P. Zhang, and J. Zhang, "Dramatic variation of the vomeronasal pheromone receptor gene repertoire among five orders of placental and marsupial mammals," Proceedings of the National Academy of Sciences of the United States of America, vol. 102, no. 16, pp. 5767-5772, 2005.

[19] B. A. Williams, R. F. Kay, and E. C. Kirk, "New perspectives on anthropoid origins," Proceedings of the National Academy of Sciences of the United States of America, vol. 107, no. 11, pp. 4797-4804, 2010.

[20] N. J. Dominy, C. F. Ross, and T. D. Smith, "Evolution of the special senses in primates: past, present, and future," Anatomical Record. Part A, vol. 281, no. 1, pp. 1078-1082, 2004.

[21] E. W. Heymann, "Scent marking strategies of New World primates," American Journal of Primatology, vol. 68, no. 6, pp. 650-661, 2006.

[22] T. D. Smith, M. I. Siegel, C. J. Bonar et al., "The existence of the vomeronasal organ in postnatal chimpanzees and evidence for its homology with that of humans," Journal of Anatomy, vol. 198, no. 1, pp. 77-82, 2001.

[23] J. M. Young and B. J. Trask, "V2R gene families degenerated in primates, dog and cow, but expanded in opossum," Trends in Genetics, vol. 23, no. 5, pp. 212-215, 2007.

[24] J. M. Young, M. Kambere, B. J. Trask, and R. P. Lane, “Divergent $\mathrm{V} 1 \mathrm{R}$ repertoires in five species: amplification in rodents, decimation in primates, and a surprisingly small repertoire in dogs," Genome Research, vol. 15, no. 2, pp. 231-240, 2005.

[25] R. A. Barton, "Olfactory evolution and behavioral ecology in primates," American Journal of Primatology, vol. 68, no. 6, pp. 545-558, 2006.

[26] E. W. Heymann, "The neglected sense-olfaction in primate behavior, ecology, and evolution," American Journal of Primatology, vol. 68, no. 6, pp. 519-524, 2006.

[27] M. J. Baum and K. R. Kelliher, "Complementary roles of the main and accessory olfactory systems in mammalian mate recognition," Annual Review of Physiology, vol. 71, pp. 141160, 2009.

[28] S. D. Munger, T. Leinders-Zufall, and F. Zufall, "Subsystem organization of the mammalian sense of smell," Annual Review of Physiology, vol. 71, pp. 115-140, 2009.

[29] F. Ankel-Simons, Primate Anatomy: An Introduction, Elsevier, Amsterdam, The Netherlands, 3rd edition, 2007.

[30] C. S. Evans, "Accessory chemosignaling mechanisms in primates," American Journal of Primatology, vol. 68, no. 6, pp. 525-544, 2006.

[31] R. A. Hayes, T. L. Morelli, and P. C. Wright, "Anogenital gland secretions of Lemur catta and Propithecus verreauxi coquereli: a preliminary chemical examination," American Journal of Primatology, vol. 63, no. 2, pp. 49-62, 2004.

[32] L. A. Knapp, J. Robson, and J. S. Waterhouse, "Olfactory signals and the MHC: a review and a case study in Lemur catta," American Journal of Primatology, vol. 68, no. 6, pp. 568-584, 2006.

[33] T. Smith, "Individual olfactory signatures in common marmosets (Callithrix jacchus)," American Journal of Primatology, vol. 68, no. 6, pp. 585-604, 2006.

[34] R. A. Hayes, T. L. Morelli, and P. C. Wright, "Volatile components of lemur scent secretions vary throughout the year," American Journal of Primatology, vol. 68, no. 12, pp. 12021207, 2006.

[35] J. Delbarco-Trillo, B. A. Burker, T. E. Goodwin, and C. M. Drea, "Night and day: the comparative study of strepsirhine primates reveals socioecological and phylogenetic patterns in olfactory signals," Journal of Evolutionary Biology, vol. 24, no. 1, pp. 82-98, 2011.

[36] N. Collias and C. Southwick, "A field study of population density and social organization in howling monkeys," Proceedings of the American Philosophical Society, vol. 96, no. 2, pp. 143-156, 1952.

[37] A. Gautier-Hion and J.-P. Gautier, "Le singe de brazza: une stratégic originale," Zeitschrift für Tierpsychologie, vol. 46, no. 1, pp. 84-104, 1978.

[38] A. T. C. Feistner, "Scent marking in mandrills, Mandrillus sphinx," Folia Primatologica, vol. 57, no. 1, pp. 42-47, 1991.

[39] T. Geissmann, "A sternal gland in the Siamang Gibbon (Hylobates syndactylus)," International Journal of Primatology, vol. 8, no. 1, pp. 1-15, 1987.

[40] T. Geissmann and B. Manella, "Steroid secretion in siamang (Symphalangus syndactylus)," Gibbon Journal, vol. 4, pp. 5663, 2008.

[41] P. G. Hepper and D. L. Wells, "Individually identifiable body odors are produced by the gorilla and discriminated by humans," Chemical Senses, vol. 35, no. 4, pp. 263-268, 2010.

[42] P. Lenochova and J. Havlicek, "Human body odour individuality," in Chemical Senses in Vertebrates, J. L. Hurst, R. J. Beynon, S. C. Roberts, and T. D. Wyatt, Eds., vol. 11, pp. 189198, Springer, New York, NY, USA, 2008.

[43] J. M. Setchell, S. Vaglio, J. Moggi-Cecchi, F. Boscaro, L. Calamai, and L. A. Knapp, "Chemical composition of scentgland secretions in an Old World monkey (Mandrillus sphinx): influence of sex, male status, and individual identity," Chemical Senses, vol. 35, no. 3, pp. 205-220, 2010.

[44] J. M. Setchell, S. Vaglio, K. M. Abbott et al., "Odour signals major histocompatibility complex genotype in an Old World monkey," Proceedings of the Royal Society B, vol. 278, no. 1703, pp. 274-280, 2011. 
[45] A. Jolly, Lemur Behavior: A Madagascar Field Study, University of Chicago Press, Chicago, Ill, USA, 1966.

[46] T. Rowell, "Review of The Study of Prosimian Behavior," Journal of Mammalogy, vol. 61, no. 2, pp. 386-388, 1980.

[47] A. Nekaris and S. Bearder, "The lorisiform primates of Asia and mainland Africa: diversity shrouded in darkness," in Primates in Perspective, C. J. Campbell, A. Fuentes, K. C. MacKinnon, M. Panger, and S. Bearder, Eds., pp. 24-45, Oxford University Press, Oxford, UK, 2007.

[48] R. D. Martin, "Origins, diversity and relationships of lemurs," International Journal of Primatology, vol. 21, no. 6, pp. 10211049, 2000.

[49] I. Tattersall, "Madagascar's lemurs: cryptic diversity or taxonomic inflation?" Evolutionary Anthropology, vol. 16, no. 1, pp. 12-23, 2007.

[50] R. A. Mittermeier, J. U. Ganzhorn, W. R. Konstant et al., "Lemur diversity in Madagascar," International Journal of Primatology, vol. 29, no. 6, pp. 1607-1656, 2008.

[51] S. D. Munger, "Noses within noses," Nature, vol. 459, no. 7246, pp. 521-522, 2009.

[52] C. Evans and A. Schilling, "The accessory (vomeronasal) chemoreceptor system in some prosimians," in Creatures of the Dark: The Nocturnal Prosimians, L. Alterman, G. A. Doyle, and M. K. Izard, Eds., pp. 393-411, Plenum Press, New York, NY, USA, 1995.

[53] F. Aujard, "Effect of vomeronasal organ removal on male socio-sexual response to female in a prosimian primate (Microcebus murinus)," Physiology and Behavior, vol. 62, no. 5, pp. 1003-1008, 1997.

[54] M. Perret, "Social influences on oestrous cycle length and plasma progesterone concentrations in the female lesser mouse lemur (Microcebus murinus)," Journal of Reproduction and Fertility, vol. 77, no. 1, pp. 303-311, 1986.

[55] P. L. Whitten and D. K. Brockman, "Strepsirhine reproductive ecology," in Reproductive Ecology and Human Evolution, P. T. Ellison, Ed., pp. 321-350, Aldine de Gruyter, New York, NY, USA, 2001.

[56] F. Aujard and M. Perret, "Age-related effects on reproductive function and sexual competition in the male prosimian primate, Microcebus murinus," Physiology and Behavior, vol. 64, no. 4, pp. 513-519, 1998.

[57] F. Aujard and F. Némoz-Bertholet, "Response to urinary volatiles and chemosensory function decline with age in a prosimian primate," Physiology and Behavior, vol. 81, no. 4, pp. 639-644, 2004.

[58] A. Schilling, "The possible role of urine in territoriality of some nocturnal prosimians," Symposia of the Zoological Society of London, vol. 45, pp. 165-193, 1980.

[59] E. Pages, "Ethoecology of Microcebus coquereli during the dry season," in Nocturnal Malagasy Primates: Ecology, Physiology and Behavior, P. Charles-Dominique, H. M. Cooper, A. Hladik et al., Eds., pp. 97-116, Academic Press, New York, NY, USA, 1980.

[60] S. K. Bearder, "Lorises, bushbabies, and tarsiers: diverse societies in solitary foragers," in Primate Societies, B. B. Smuts, D. L. Cheney, R. M. Seyfarth, R. W. Wrangham, and T. T. Struhsaker, Eds., pp. 11-24, University of Chicago Press, Chicago, Ill, USA, 1987.

[61] M. Perret, "Chemocommunication in the reproductive function of mouse lemurs," in Creatures of the Dark: The Nocturnal Prosimians, L. Alterman, G. A. Doyle, and M. K. Izard, Eds., pp. 377-392, Plenum Press, New York, NY, USA, 1995.
[62] P. Braune, S. Schmidt, and E. Zimmermann, "Spacing and group coordination in a nocturnal primate, the golden brown mouse lemur (Microcebus ravelobensis): the role of olfactory and acoustic signals," Behavioral Ecology and Sociobiology, vol. 58, no. 6, pp. 587-596, 2005.

[63] K. F. Stanger, B. S. Coffman, and M. K. Izard, "Reproduction in Coquerel's Dwarf Lemur (Mirza coquereli)," American Journal of Primatology, vol. 36, no. 3, pp. 223-237, 1995.

[64] K. Bailey, "Flehmen in the ring-tailed lemur (Lemur catta)," Behaviour, vol. 65, pp. 309-319, 1978.

[65] A. Schilling, "Seasonal variation in the fecal marking of Cheirogaleus medius in simulated climatic conditions," in Nocturnal Malagasy Primates: Ecology, Physiology and Behavior, P. Charles-Dominique, H. M. Cooper, A. Hladik et al., Eds., pp. 181-190, Academic Press, New York, NY, USA, 1980.

[66] P. Charles-Dominique and J.-J. Petter, "Ecology and social life of Phaner furcifer," in Nocturnal Malagasy Primates: Ecology, Physiology and Behavior, P. Charles-Dominique, $\mathrm{H}$. M. Cooper, A. Hladik et al., Eds., pp. 75-95, Academic Press, New York, NY, USA, 1980.

[67] J.-J. Petter, A. Schilling, and G. Pariente, "Observations on behavior and ecology of Phaner furcifer," in Lemur Biology, I. Tattersall and R. W. Sussman, Eds., pp. 209-218, New York, NY, USA, Plenum Press, 1975.

[68] P. Charles-Dominique and C. M. Hladik, "Le lepilemur du sud de Madagascar: ecologie, alimentation, et vie sociale," Revue d'Ecologie (La Terre et la Vie), vol. 25, no. 1, pp. 3-66, 1971.

[69] I. Tattersall, The Primates of Madagascar, Columbia University Press, New York, NY, USA, 1982.

[70] E. J. Sterling, "Patterns of range use and social organization in aye-ayes (Daubentonia madagascariensis) on Nosy Mangabe," in Lemur Social Systems and Their Ecological Basis, P. M. Kappeler and J. U. Ganzhorn, Eds., pp. 1-10, Plenum Press, New York, NY, USA, 1993.

[71] J.-J. Petter and A. Peyrieras, "Nouvelle contribution a l'etude d'un lemurien malgache, le aye-aye (Daubentonia madagascariensis E. Geoffroy)," Mammalia, vol. 34, pp. 167193, 1970.

[72] J.-J. Petter, “The Aye-aye," in Primate Conservation, P. Ranier and G. H. Bourne, Eds., pp. 37-57, Academic Press, New York, NY, USA, 1977.

[73] S. K. Bearder and G. A. Doyle, "Ecology of bushbabies Galago senegalensis and Galago crassicaudatus, with some notes on their behaviour in the field," in Prosimian Biology, R. D. Martin, G. A. Doyle, and A. C. Walker, Eds., pp. 109-130, Duckworth, London, UK, 1974.

[74] G. A. Doyle, "The behaviour of the lesser bushbaby," in Prosimian Biology, R. D. Martin, G. A. Doyle, and A. C. Walker, Eds., pp. 213-231, Duckworth, London, UK, 1974.

[75] P. Charles-Dominique, Ecology and Behavior of Nocturnal Primates: Prosimians of Equatorial West Africa, Duckworth, London, UK, 1977.

[76] R. J. Andrew and R. B. Klopman, "Urine-washing: comparative notes," in Prosimian Biology, R. D. Martin, G. A. Doyle, and A. C. Walker, Eds., pp. 303-312, Duckworth, London, UK, 1974.

[77] M. K. Izard and D. T. Rasmussen, "Reproduction in the slender loris (Loris tardigradus malabaricus)," American Journal of Primatology, vol. 8, no. 2, pp. 153-165, 1985. 
[78] A. B. Clark, "Scent marks as social signals in Galago crassicaudatus I. Sex and reproductive status as factors in signals and responses," Journal of Chemical Ecology, vol. 8, no. 8, pp. 1133-1151, 1982.

[79] A. B. Clark, "Scent marks as social signals in Galago crassicaudatus II. Discrimination between individuals by scent," Journal of Chemical Ecology, vol. 8, no. 8, pp. 1153-1165, 1982.

[80] P. Charles-Dominique, "Urine marking and territoriality in Galago alleni (Waterhouse, 1837-Lorisoidea, Primates)-a field study by radio-telemetry," Zeitschrift fur Tierpsychologie, vol. 43, no. 2, pp. 113-138, 1977.

[81] S. L. Watson, J. P. Ward, K. B. Davis, and R. C. Stavisky, "Scent-marking and cortisol response in the small-eared bushbaby (Otolemur garnettii)," Physiology and Behavior, vol. 66, no. 4, pp. 695-699, 1999.

[82] K. A. I. Nekaris, E. R. Pimley, and K. M. Ablard, "Predator defense by slender lorises and pottos," in Primate AntiPredator Strategies, S. Gursky and K. A. I. Nekaris, Eds., pp. 222-240, Springer, New York, NY, USA, 2007.

[83] H. Schulze and B. Meier, "Behavior of captive Loris tardigradus nordicus: a qualitative description, including some information about morphological bases of behavior," in Creatures of the Dark: The Nocturnal Prosimians, L. Alterman, G. A. Doyle, and M. K. Izard, Eds., pp. 221-249, Plenum Press, New York, NY, USA, 1995.

[84] K. A. I. Nekaris, "Social lives of adult mysore slender lorises (Loris lydekkerianus lydekkerianus)," American Journal of Primatology, vol. 68, no. 12, pp. 1171-1182, 2006.

[85] G. H. Manley, "Functions of the external genital glands of Perodicticus and Arctocebus," in Prosimian Biology, R. D. Martin, G. A. Doyle, and A. C. Walker, Eds., pp. 313-329, Duckworth, London, UK, 1974.

[86] J. Epps, "Social interactions of Perodicticus potto kept in captivity in Kampala, Uganda," in Prosimian Biology, R. D. Martin, G. A. Doyle, and A. C. Walker, Eds., pp. 233-244, Duckworth, London, UK, 1974.

[87] E. R. Pimley, S. K. Bearder, and A. F. Dixson, "Social organization of the Milne-Edward's potto," American Journal of Primatology, vol. 66, no. 4, pp. 317-330, 2005.

[88] H. S. Fisher, R. R. Swaisgood, and H. Fitch-Snyder, "Countermarking by male pygmy lorises (Nycticebus pygmaeus): do females use odor cues to select mates with high competitive ability?" Behavioral Ecology and Sociobiology, vol. 53, no. 2, pp. 123-130, 2003.

[89] H. S. Fisher, R. R. Swaisgood, and H. Fitch-Snyder, "Odor familiarity and female preferences for males in a threatened primate, the pygmy loris Nycticebus pygmaeus: applications for genetic management of small populations," Naturwissenschaften, vol. 90, no. 11, pp. 509-512, 2003.

[90] I. Tattersall and R. W. Sussman, "Observations on the ecology and behavior of the Mongoose Lemur Lemur mongoz mongoz Linnaeus (Primates, Lemuriformes), at Ampijoroa, Madagascar," in Anthropological Papers of the American Museum of Natural History, vol. 52, no. 4, pp. 193-216, 1975.

[91] D. J. Curtis, The Mongoose Lemur (Eulemur mongoz). A Study in Behaviour and Ecology, Ph.D. dissertation, Universitat Zurich, 1997.

[92] D. J. Curtis and A. Zaramody, "Social structure and seasonal variation in the behaviour of Eulemur mongoz," Folia Primatologica, vol. 70, no. 2, pp. 79-96, 1999.
[93] D. J. Overdorff, Ecological correlates to social structure in two prosimian primates: Eulemur fulvus rufus and Eulemur rubriventer, Ph.D. dissertation, Duke University, Durham, NC, USA, 1991.

[94] D. J. Overdorff and S. R. Tecot, "Social pair-bonding and resource defense in wild red-bellied Lemurs (Eulemur rubriventer)," in Lemurs: Ecology and Adaptation, L. Gould and M. Sauther, Eds., pp. 235-254, Springer, New York, NY, USA, 2006.

[95] P. M. Kappeler, "A preliminary study of olfactory behavior of captive Lemur coronatus during the breeding season," International Journal of Primatology, vol. 9, no. 2, pp. 135146, 1988.

[96] B. Z. Freed, Co-occurrence among crowned Lemurs (Lemur coronatus) and Sanford's Lemurs (Lemur fulvus sanfordi) of Madagascar, Ph.D. dissertation, Washington University, St. Louis, Mo, USA, 1996.

[97] I. Fornasieri and J. J. Roeder, "Marking behaviour in two lemur species (L. fulvus and L. macaco): relation to social status, reproduction, aggression and environmental change," Folia Primatologica, vol. 59, no. 3, pp. 137-148, 1992.

[98] L. Koenders, "An eco-ethological comparison of Lemur fulvus and Lemur macaco," Human Evolution, vol. 4, no. 2-3, pp. 187-193, 1989.

[99] L. Koenders, Y. Rumpler, and P. Ropartz, "Differences in male-female interaction between Lemur fulvus and $L$. macaco," Primates, vol. 26, no. 2, pp. 195-201, 1985.

[100] I. C. Colquhoun, "The socioecology of Eulemur macaco: a preliminary report," in Lemur Social Systems and Their Ecological Basis, P. M. Kappeler and J. U. Ganzhorn, Eds., pp. 11-23, Plenum Press, New York, NY, USA, 1993.

[101] I. C. Colquhoun, A predictive socioecological study of the black Lemur (Eulemur macaco macaco) in Northwestern Madagascar, Ph.D. dissertation, Washington University, St. Louis, Mo, USA, 1997.

[102] J. E. Harrington, "Olfactory communication in Lemur fulvus," in Prosimian Biology, R. D. Martin, G. A. Doyle, and A. C. Walker, Eds., pp. 331-346, Duckworth, London, UK, 1974.

[103] C. F. Chandler, "Development and function of marking and sexual behavior in the malagasy prosimian primate, Lemur fulvus," Primates, vol. 16, no. 1, pp. 35-47, 1975.

[104] J. E. Harrington, "Field observations of social behavior of Lemur fulvus fulvus E. Geoffroy 1812," in Lemur Biology, I. Tattersall and R. W. Sussman, Eds., pp. 259-279, Plenum Press, New York, NY, USA, 1975.

[105] L. G. Vick and J. M. Conley, "An ethogram for Lemur fulvus," Primates, vol. 17, no. 2, pp. 125-144, 1976.

[106] J. E. Harrington, "Discrimination between individuals by scent in Lemur fulvus," Animal Behaviour, vol. 24, no. 1, pp. 207-212, 1976.

[107] J. E. Harrington, "Discrimination between males and females by scent in Lemur fulvus," Animal Behaviour, vol. 25, no. 1, pp. 147-151, 1977.

[108] J. E. Harrington, "Diurnal behavior of Lemur mongoz at Ampijoroa, Madagascar," Folia Primatologica, vol. 29, no. 4, pp. 291-302, 1978.

[109] J. E. Harrington, "Responses of Lemur fulvus to scents of different subspecies of $L$. fulvus and to scents of different species of lemuriformes," Zeitschrift fur Tierpsychologie, vol. 49, no. 1, pp. 1-9, 1979. 
[110] L. Gould and D. J. Overdorff, "Adult male scent-marking in Lemur catta and Eulemur fulvus rufus," International Journal of Primatology, vol. 23, no. 3, pp. 575-586, 2002.

[111] C. M. Nievergelt, T. Mutschler, and A. T. C. Feistner, "Group encounters and territoriality in wild Alaotran gentle lemurs (Hapalemur griseus alaotrensis)," American Journal of Primatology, vol. 46, no. 3, pp. 251-258, 1998.

[112] T. Mutschler, C. M. Nievergelt, and A. T. C. Feistner, "Social organization of the Alaotran gentle lemur (Hapalemur griseus alaotrensis)," American Journal of Primatology, vol. 50, no. 1, pp. 9-24, 2000.

[113] D. Haring and K. Davis, "Management of the grey gentle or Eastern lesser Bamboo Lemur Hapalemur griseus griseus at Duke University Primate Center, Durham," International Zoo Yearbook, vol. 36, no. 1, pp. 20-34, 1998.

[114] C. I. Bargmann, "Comparative chemosensation from receptors to ecology," Nature, vol. 444, no. 7117, pp. 295-301, 2006. 

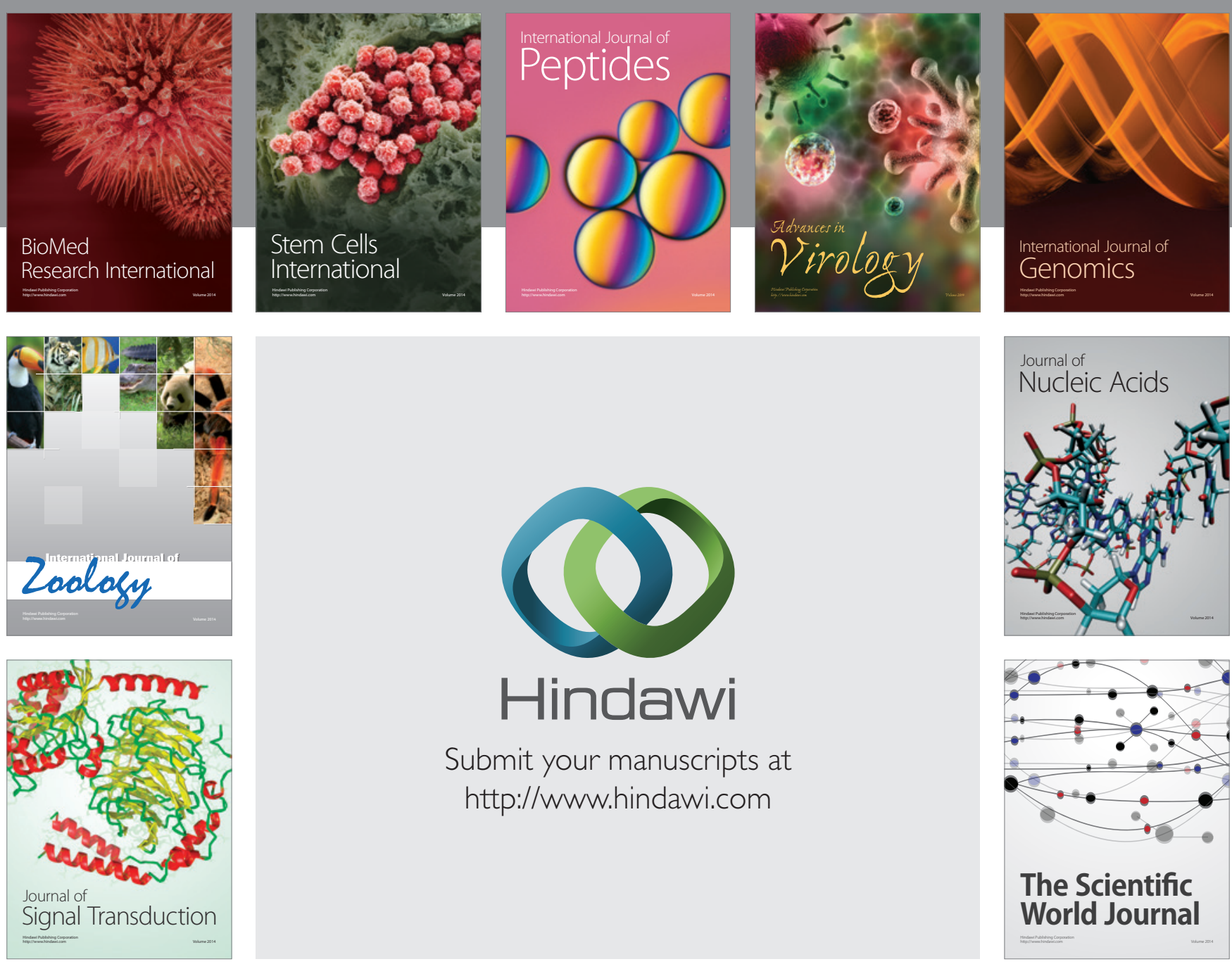

Submit your manuscripts at

http://www.hindawi.com
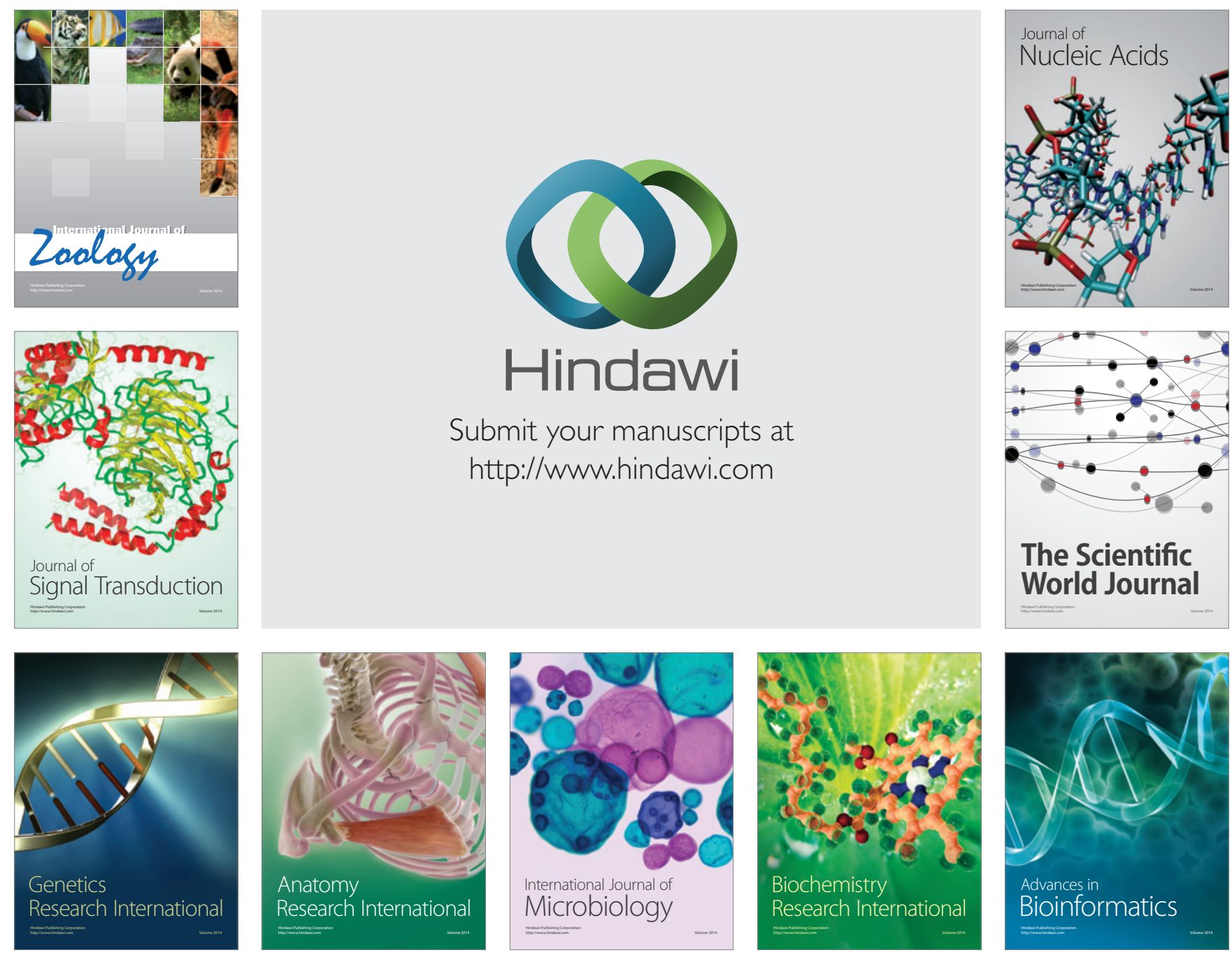

The Scientific World Journal
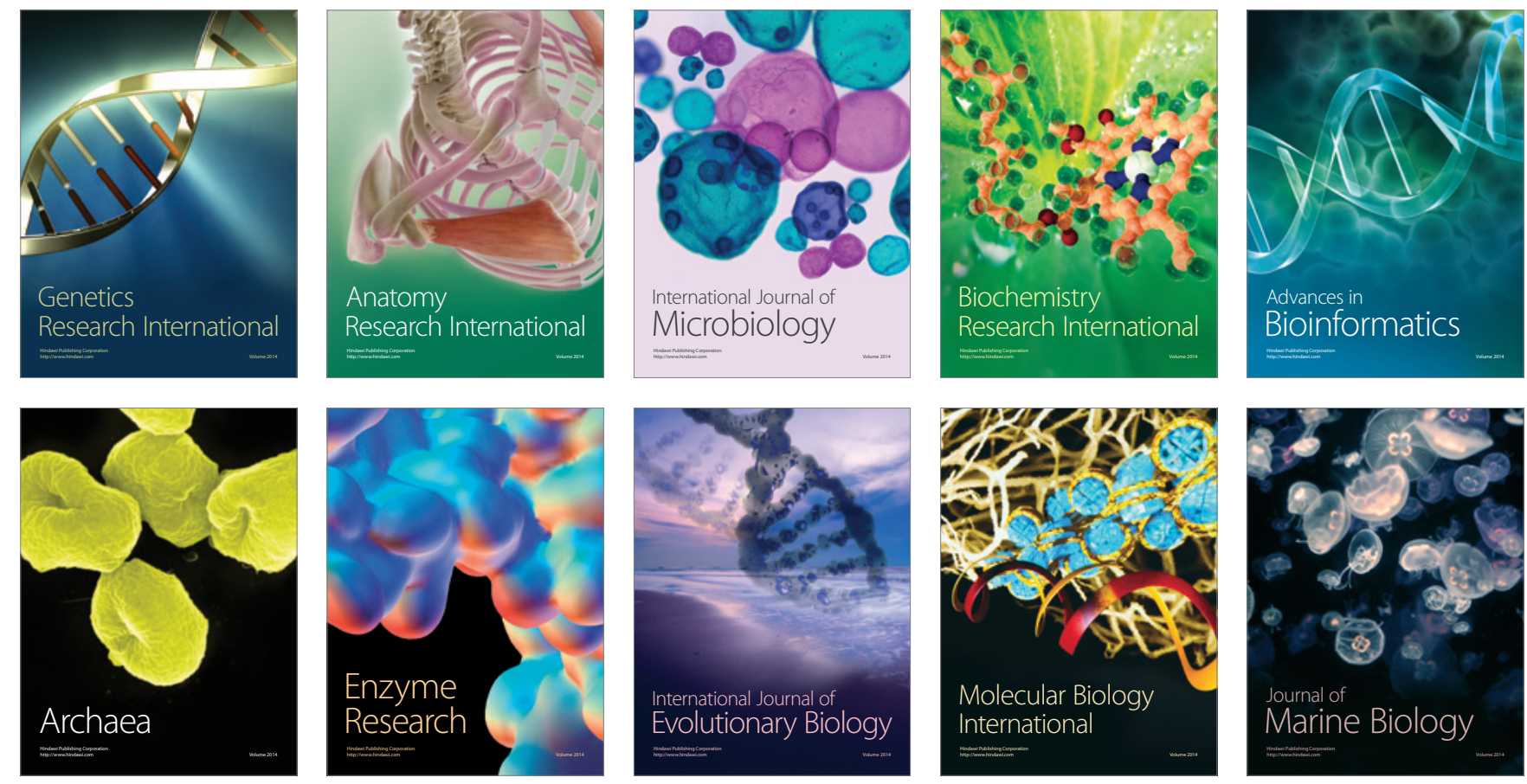